\title{
Transkateter aortaventilimplantasjon ved aortastenose
}

\author{
Sammendrag \\ Bakgrunn. Vi presenterer korttids- \\ resultater fra det første året med trans- \\ kateter aortaventilimplantasjon (TAVI) \\ ved aortastenose ved Universitetssyke- \\ huset Nord-Norge.
}

Materiale og metode. Fra september 2008 til september 2009 ble 25 pasienter med aortastenose behandlet med metoden. Kontrollgruppe var 25 sammenliknbare pasienter operert med åpen teknikk laortic valve replacement, AVR).

Resultater. De som var operert med transkateter aortaventilimplantasjon, hadde høyere EuroSCORE ( $p<0,001)$. Ingen hadde behov for opphold $\mathrm{i}$ intensivavdeling. I gruppen operert med konvensjonell åpen teknikk var det 38 intensivdøgn. Operasjonstiden var kortere i gruppen med transkateter aortaventilimplantasjon enn i kontrollgruppen $(p<0,001)$, og klaffeprotesene var større i førstnevnte gruppe $(p<0,01)$. Antallet postoperative transfusjoner var lavere i gruppen med transkateter aortaventilimplantasjon ( $p<0,01)$. Ingen i denne gruppen fikk perioperativt hjerteinfarkt eller hjerneslag, mens én av dem med åpen operasjon fikk hjerteinfarkt og én hjerneslag. Postoperativ transvalvulær middelgradient ble redusert i begge grupper ( $p<0,001)$ og var lavere i gruppen med transkateter aortaventilimplantasjon $(p=0,001)$. NYHA-klasse ble bedret etter transkateter aortaventilimplantasjon ( $p<0,001$ ). Ingen fikk behov for permanent pacemaker. 30-dagersmortaliteten var én i gruppen med transkateter aortaventilimplantasjon, mot fire i kontrollgruppen. Etter utskrivning døde en pasient i hver gruppe.

Fortolkning. Transkateter aortaventilimplantasjon er en trygg og effektiv metode hos en selektert gruppe med aortastenose vurdert som høyrisikopasienter når det gjelder konvensjonell åpen teknikk.

> Se også side 331, 342
Terje K. Steigen

terje.steigen@unn.no

Hjertemedisinsk avdeling

Universitetssykehuset Nord-Norge

9038 Tromsø

og

Institutt for klinisk medisin

Universitetet i Troms $\varnothing$

\section{Børge Schive}

Hjertemedisinsk avdeling

Torvind Næsheim

Anestesiavdelingen

Universitetssykehuset Nord-Norge

\section{Rolf Busund}

Hjerte-, lunge- og karkirurgisk avdeling Universitetssykehuset Nord-Norge og

Institutt for klinisk medisin

Universitetet i Troms $\varnothing$

Aortastenose er den vanligste ervervede klaffelidelse i den vestlige verden, med en insidens på ca. $5 \%$ hos dem over 75 år (1). Insidensen øker med økende alder, og pasientene har ofte betydelig komorbiditet. Sikre tall på forekomsten i Norge finnes ikke, men årlig opereres ca. 1500 mennesker for klaffesykdom her i landet (2). Antall personer med aortastenose forventes å øke i takt med stigende gjennomsnittlig levealder. Ubehandlet har sykdommen dårlig prognose. Ved medisinsk behandling av uttalt, symptomgivende aortastenose er ettårs- og femårsoverlevelsen henholdsvis $60 \%$ og $32 \%$ (3). Prognosen er dermed sammenliknbar med prognosen ved mange aggressive kreftformer.

Åpen kirurgisk implantasjon av kunstig hjerteklaff har vært gullstandard for behandling av symptomgivende aortastenose i flere tiår. Dette gir betydelig symptomlindring og høyere overlevelse enn medikamentell behandling $(4,5)$. Likevel viser europeiske registerdata (6) at omkring en tredel av dem $>75$ år med uttalt symptomgivende aortastenose i NYHA-funksjonsklasse III/IV (New York Heart Association) ikke får tilbud om kirurgisk behandling på grunn av høy alder, nedsatt venstre ventrikkel-funksjon, betydelig komorbiditet eller antatt reduserte leveutsikter.

Henning Rud Andersen og medarbeidere publiserte i 1992 dyreforsøk med perkutan transluminal implantasjon av aortaklaff (7). Teknikken er senere videreutviklet til bruk hos mennesker (8). Ved å komprimere stentmonterte biologiske klaffer til liten diameter kan de føres i posisjon og implanteres retrograd via femoralarterien (9) eller antegrad via apeks av hjertet (10). Begge tilganger kan benyttes på bankende hjerte, uten bruk av hjerte-lunge-maskin. Den første implantasjon hos et menneske ble utført i Frankrike i april 2002 (8). Siden har teknikken fătt stor utbredelse hos pasienter med høy kirurgisk risiko.

Per desember 2009 var, ifølge klaffeprodusentene, ca. 10000 personer behandlet med transkateter aortaventilimplantasjon (TAVI) på verdensbasis. I dag er to forskjellige hovedprinsipper i klinisk bruk: en ballongekspanderbar stentbasert klaffeprotese (Edwards SAPIEN, Edwards Lifesciences, Irvine, CA) (fig 1) og en selvekspanderende nitinolstentklaffeprotese (CoreValve, Medtronic CV Luxembourg S.a.r.l) (fig 2).

Ved Feiringklinikken ble ti pasienter behandlet med CoreValve i januar/februar 2008. Programmet ble imidlertid stanset av daværende direktør ved klinikken (11). Metoden ble så vurdert av Nasjonalt råd for kvalitet og prioritering i helsetjenesten. De anså den som eksperimentell, og rådets anbefaling fra 8.9. 2008 var at transkateter aortaventilimplantasjon ikke skulle tilbys norske pasienter på daværende tidspunkt (12). Innstillingen gikk på tvers av anbefalinger fra det kardiologiske og det thoraxkirurgiske fagmiljøet i Norge, som mente metoden var utprøvende, ikke eksperimentell.

Ved Universitetssykehuset Nord-Norge var vi på dette tidspunktet kommet så langt $\mathrm{i}$ forberedelsene at vi likevel valgte å starte opp programmet. Andre aktuelle universitetsklinikker ville vente. Siden metoden var etablert og godt utprøvd ved mange utenlandske sentre og således etter vår vurdering ikke var å betrakte som eksperimentell,

\section{Hovedbudskap}

- Transkateter aortaventilimplantasjon var en trygg metode hos utvalgte pasienter

- Korttidsresultatene var likeverdige med resultatene ved åpen kirurgi hos en sammenliknbar gruppe

- Suksessfaktorer er grundig opplæring. pasientseleksjon og utredning og et velfungerende multidisiplinært team 


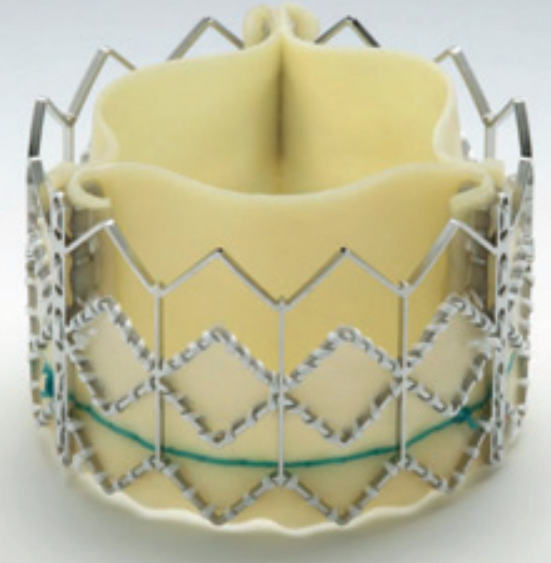

Figur 1 Transkateter hjerteklaff, ballongekspanderbar, Edwards SAPIEN. Gjengitt med tillatelse fra produsenten

mente vi at etablering ikke var å anse som et forskningsprosjekt. Vi fant det derfor ikke nødvendig å søke forhåndsgodkjenning fra forskningsetisk komité. De første to behandlingene ble vellykket gjennomført 24.9. 2008. Senere har Rikshospitalet, Haukeland universitetssykehus og St. Olavs hospital startet med behandlingen.

Vi presenterer her resultatene fra de første 25 implantasjonene, som ble utført i perioden september 2008 til september 2009. Til sammenlikning presenterer vi data fra 25 operasjoner utført på tradisjonelt vis hos de eldste pasientene med høyest risiko i perioden januar 2008 til september 2009.

\section{Materiale og metode} Pasientutvelgelse

I perioden fra september 2008 til og med august 2009 ble det ved Universitetssykehuset Nord-Norge utført transkateter aortaventilimplantasjon hos 25 pasienter. Seleksjonskriteriene var de samme som ble benyttet internasjonalt. For å bli akseptert til behandling måtte pasienten være 80 år eller eldre og ha uttalt symptomgivende aortastenose. I tillegg måtte det være en operativ risiko for død på $>20 \%$, vurdert med logistisk European system for cardiac operative risk evaluation (EuroSCORE) (13), eller pasienten måtte være uegnet for åpen kirurgi grunnet komorbiditet som ikke inngår i EuroSCORE-beregningen.

Pasienter med utbredte kalknedslag i a. ascendens (porselensaorta) ble akseptert til behandling selv om de var under 80 år. De som trengte samtidig kirurgisk koronar revaskularisering, hadde blødningsforstyrrelser, leveutsikter på under ett år eller a. annulus-diameter på $<18 \mathrm{~mm}$ eller $>25 \mathrm{~mm}$ målt med oesophagusekkokardiografi ble ekskludert. Pasientutvelgelsen var basert på konsensus $i$ et team av erfarne kardiologer og thoraxkirurger. Grunnet innstillingen fra nasjonalt råd og fordi vi anså metoden for å være utprøvende valgte vi å innhente skriftlig informert samtykke fra pasientene.

\section{Utredning}

97 pasienter over 80 år med aortastenose som ble henvist $\mathrm{i}$ inklusjonsperioden ble vurdert for enten åpen operasjon (AVR) eller transkateter aortaventilimplantasjon. I tillegg ble noen få pasienter under 80 år som var uaktuelle for åpen kirurgi vurdert for kateterbasert implantasjon. Aktuelle pasienter ble utredet med transtorakal og transøsofageal ekkokardiografi, selektiv koronar angiografi, CT totalaorta og bekkenarterier samt spirometri. Angiografi av aortarot og iliaka-/femoralkar ble systematisk gjort hos de første 15 pasientene, men ble etter hvert erstattet med CT med tredimensjonal rekonstruksjon.

De som hadde slyngede, trange, betydelig forkalkede bekkenkar og/eller uttalt aterosklerose i aortabuen ble selektert til transapikal implantasjon, for å unngå vaskulære og emboliske komplikasjoner. Transfemoral teknikk ble valgt når det ut fra de radiografiske data lå godt til rette for det (e-ramme 1). Ingen ble ekskludert på grunn av tilgangsproblemer.

\section{Implantasjonsprosedyre}

Alle prosedyrene ble utført i et hybridlaboratorium, som er en fullt utstyrt operasjonsstue med moderne angiografirøntgen og monitoreringsutstyr. Hjerte-lunge-maskin ble rutinemessig klargjort i tilfelle det skulle oppstå behov for sirkulasjonsstøtte eller konvertering til åpen kirurgi.

Etter teoretisk opplæring og simulatortrening ble de første prosedyrene (fire transfemorale og to transapikale) utført sammen med intervensjonskardiolog/kirurg fra europeiske sentre der man hadde omfattende erfaring med metoden. To faste hjerteanestesiologer var tilknyttet programmet. Pasientene fikk anlagt invasiv blodtrykksmåling

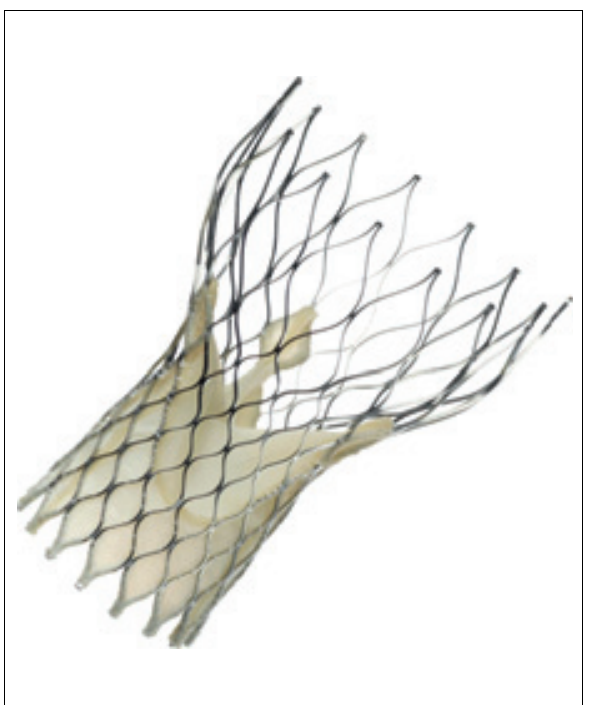

Figur 2 Medtronic Corevalve selvekspanderende aortaklaffprotese, ekspandert. Gjengitt med tillatelse fra produsenten

og sentral venøs trykkmåling før innledning av narkose. Det ble benyttet kontinuerlig aktiv varming under prosedyren. Avhengig av hemodynamikk ble pasienten væskebelastet og behandlet med intravenøs infusjon av noradrenalin eller dopamin i lave doser. Innledning og vedlikehold av anestesien ble gjort med henholdsvis fentanyl, Penthothal, Midazolam, Ketalar, Norcuron, Sevorane og isofluran, etter den enkelte anestesiologs preferanser. Lokalanestesi ble benyttet på incisjonssteder samt i pharynx og larynx. Transøsofageal ekkoprobe ble anlagt umiddelbart etter innledning av anestesien og ble benyttet for å vurdere hemodynamikk og dosering av væske og kardiovasoaktive medikamenter. Pasientene ble overvåket med elektrokardiografi, timediurese, aktivert koagulasjonstid (ACT), temperatur og repeterte blodgassmålinger. Blodsparende tiltak (cellsaver) ble benyttet ved behov for autolog blodtransfusjon.

Transfemoral og transapikal prosedyre ble utført i henhold til tidligere beskrivelser $(9,10)$. Transfemoral tilgang ble gjort kirurgisk med et ca. $8 \mathrm{~cm}$ langt hudsnitt i lysken med fridissekering av a. og v. femoralis før direkte punksjon av arterien. Transapikal tilgang ble gjort gjennom ultralydveiledet anterior minitorakotomi fulgt av direkte nålepunksjon av apeks av venstre ventrikkel.

Valvuloplastikk ble gjort før klaffeimplantasjonen hos alle pasientene. Valvuloplastikk og klaffeimplantasjon ble utført ved et middelblodtrykk på ca. $50 \mathrm{~mm} \mathrm{Hg}$ under pågående hurtigpacing (frekvens ca. 200/ min) med temporær pacemaker (14) (fig 3). Blodtrykksnedsettelsen reduserer risikoen for ballongembolisering ved valvuloplastikken og for klaffeembolisering under implantasjonen.

Edwards SAPIEN-perikardklaffer (Edwards Lifesciences, Irvine, CA) ble benyttet ved alle prosedyrene. 


\section{Kontrollgruppe}

I perioden januar 2008 til september ble 39 pasienter over 80 år operert med konvensjonell åpen kirurgi for aortastenose. Ved åpen kirurgi åpnes thorax med sternotomi, aorta åpnes over klaffenivå, den gamle klaffen klippes bort og en ny klaff sys inn på plassen til den gamle. Mens dette foregår er pasientens hjerte stoppet og sirkulasjonen besørget av en hjerte-lunge-maskin. Som kontrollgruppe valgte vi de 25 pasientene som hadde høyest logistisk EuroSCORE. Kontrollgruppen var sammenliknbar med henblikk på alder, kjønn og komorbiditet. Utover dette ble det ikke gjort forsøk på matching av gruppene. Alle pasientene med transkateter aortaventilimplantasjon ble fulgt opp prospektivt ved Universitetssykehuset NordNorge, mens pasientene i kontrollgruppen for en stor del ble kontrollert ved lokalsykehusene i regionen. Av den grunn har vi ikke komplette oppfølgingsdata for kontrollgruppen.

\section{Datainnsamling og resultatmål}

Kliniske og ekkokardiografiske data ble registrert før behandlingen, postoperativt før utreise og etter én, tre, seks og 12 måneder i gruppen som fikk transkateter aortaventilimplantasjon, men bare preoperativt og postoperativt før utreise i gruppen med åpen operasjon. Ingen pasienter i den første gruppen falt ut av kontrollsystemet.

Vellykket prosedyre ble definert som tilfredsstillende implantasjon og fungerende klaff i aortaposisjon. Prosedyrerelaterte hendelser ble definert som hendelser under eller etter prosedyren og direkte relatert til den.

Perioperative resultatmål var vellykket prosedyre, 30-dagersmortalitet, større kardio- og cerebrovaskulære hendelser, endring i ekkokardiografisk middelgradient over aortaklaffen, reintervensjon/reoperasjon, transfusjoner, antall intensivdøgn og liggedager. Resultatmålene ved kontroll etter tre, seks og 12 måneder var død, kardio- og cerebrovaskulære hendelser, reintervensjon/reoperasjon, nyoppstått pacemakerbehov, kardiovaskulær status, ekkokardiografisk middelgradient over aortaklaffen og funksjonell status (NYHA-klasse).

\section{Statistikk}

Forskjeller mellom de to gruppene ble analysert med Mann-Whitneys U-test for kontinuerlige variabler og Fishers eksakte test for kategoriske variabler.

\section{Resultater}

\section{Demografiske karakteristika}

Materialet omfatter 25 pasienter behandlet med transkateter aortaventilimplantasjon og en kontrollgruppe med 25 pasienter behandlet med konvensjonell åpen kirurgi for aortastenose. I den forstnevnte gruppen ble ti pasienter selektert til transfemoral tilgang og 15 til transapikal tilgang. Demografiske variabler og komorbiditet er presentert i tabell 1 . Det var ingen signifikante forskjeller mellom

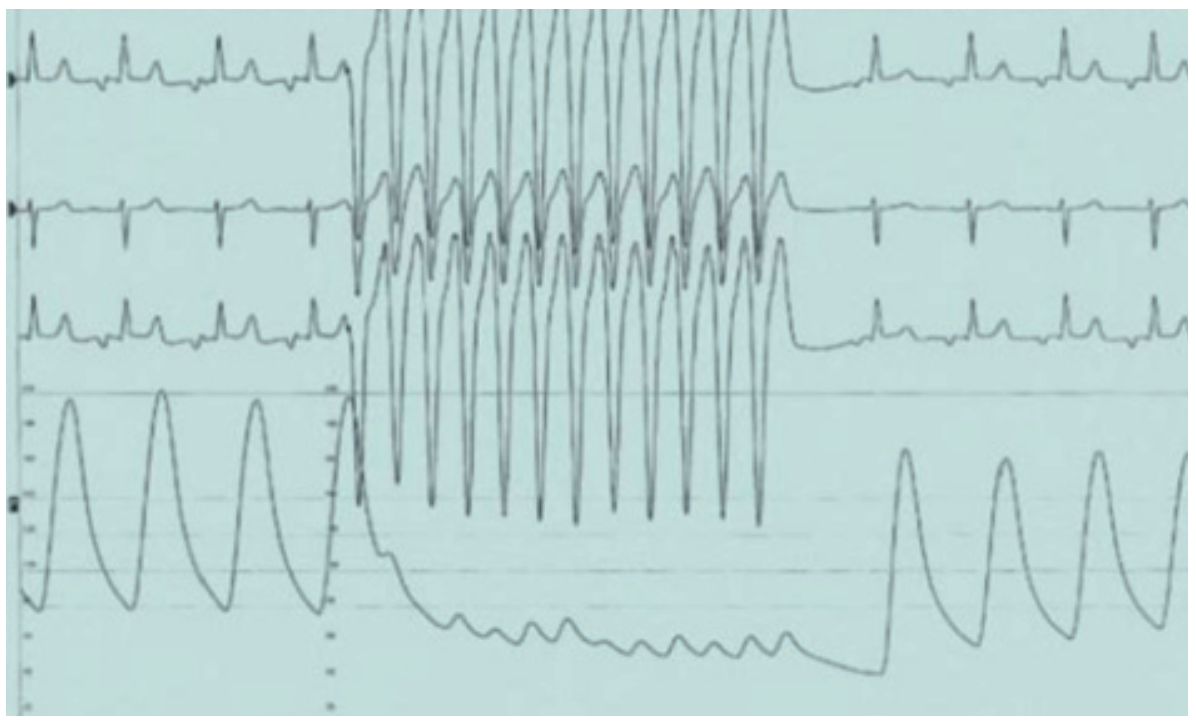

Figur 3 EKG og aortatrykk ved hurtig pacing med temporær pacemaker

de to gruppene med henblikk på demografiske variabler, komorbiditet, antall tidligere åpne hjerteinngrep, NYHA-klasse, venstre ventrikkel-funksjon eller gradient over aortaklaffen. Pasientene behandlet med transkateter aortaventilimplantasjon hadde høyere EuroSCORE $(p<0,001)$ og høyere gjennomsnittlig ASA-klasse $(\mathrm{p}<0,001)$.

\section{Perioperativt}

Alle de kateterbaserte implantasjonene var vellykket, og samtlige pasienter ble ekstu- bert på operasjonsbordet etter prosedyren (tab 2). Ingen ble konvertert til åpen kirurgi. En pasient ble konvertert fra transfemoral til transapikal tilgang grunnet forkalkninger $\mathrm{i}$ bekkenkarene. Operasjonstiden var kortere i gruppen med kateterbasert implantasjon enn $i$ gruppen med åpen operasjon $(p<0,001)$, og klaffene var større i den førstnevnte gruppen $(\mathrm{p}<0,01)$.

Tre pasienter i gruppen med transkateter aortaventilimplantasjon, to med transapikal og en med transfemoral tilgang, ble reope-

Tabell 1 Pasientkarakteristika

\begin{tabular}{|c|c|c|c|}
\hline Demografi og komorbiditet & $\begin{array}{c}\text { Åpen operasjon } \\
2008-09 \\
(n=25)\end{array}$ & $\begin{array}{c}\text { Transkateter } \\
\text { aortaventilimplantasjon } \\
2008-09 \\
(\mathrm{n}=25)\end{array}$ & P-verdi \\
\hline Alder (år), gjennomsnitt (spredning) & $82,7(79-93)$ & $84,5(76-94)$ & 0,11 \\
\hline Kjønn $(\mathrm{m} / \mathrm{k})$ & $7 / 18$ & $6 / 19$ & 1,0 \\
\hline Diabetes & 3 & 4 & 1,0 \\
\hline Tidligere slag/TIA & 3 & 3 & 1,0 \\
\hline Tidligere hjerteinfarkt & 6 & 10 & 0,36 \\
\hline Nyresvikt (kreatinin > 200) & 0 & 1 & 1,0 \\
\hline Alvorlig kols & 4 & 5 & 1,0 \\
\hline Perifer karsykdom & 3 & 9 & 0,09 \\
\hline Koronarsykdom & 13 & 15 & 0,78 \\
\hline Atrieflimmer & 4 & 9 & 0,19 \\
\hline Tidligere åpen hjerteoperasjon & 0 & 2 & 0,49 \\
\hline NYHA-klasse, gjennomsnitt & 3,0 & 3,0 & 0,98 \\
\hline ॥ & 5 & 3 & \\
\hline III & 14 & 18 & \\
\hline IV & 6 & 4 & \\
\hline $\begin{array}{l}\text { Venstre ventrikkels ejeksjonsfraksjon, } \\
\text { gjennomsnitt (spredning) }\end{array}$ & $59,4(21-80)$ & $55,5(18-75)$ & 0,22 \\
\hline $\begin{array}{l}\text { Gjennomsnittlig middelgradient } \\
\text { mm Hg (spredning) }\end{array}$ & $66,9(48-100)$ & $73,3(44-120)$ & 0,26 \\
\hline Gjennomsnittlig ASA-klasse & 3,2 & 3,8 & $<0,001$ \\
\hline Logistisk EuroSCORE (spredning) & $15,5(8-31)$ & $27,1(11-54)$ & $<0,001$ \\
\hline
\end{tabular}


rert for blødning. I gruppen med åpen operasjon ble en pasient reoperert for blødning og tre for infeksjon. Det var færre postoperative transfusjoner i gruppen med transkateter aortaventilimplantasjon $(\mathrm{p}<0,01)$. Ingen pasienter i denne gruppen fikk perioperativt hjerteinfarkt eller hjerneslag, mens i gruppen med åpen operasjon fikk én pasient hjerteinfarkt og én hjerneslag.

30-dagersmortaliteten var én i gruppen med transkateter aortaventilimplantasjon, mot fire i gruppen med åpen operasjon. Ingen fikk behov for permanent pacemaker. Ingen av pasientene med transkateter aortaventilimplantasjon hadde behov for opphold $\mathrm{i}$ intensivavdeling, mens pasientene med åpen operasjon hadde 38 intensivdøgn. En pasient i gruppen med transkateter aortaventilimplantasjon med betydelig svekket venstre ventrikkel-funksjon (EF 15-20\%) fikk utført prosedyren under sirkulasjonsstøtte fra hjerte-lunge-maskin.

\section{Oppfølging}

Median oppfølgingstid var 13 måneder (spredning 5-16 md.) i gruppen med transkateter aortaventilimplantasjon og 12 måneder (spredning 4-24 md.) i for dem med åpen operasjon. I oppfølgingstiden døde en pasient i hver gruppe, henholdsvis tre måneder postoperativt (åpen operasjon) og fire måneder postoperativt (transkateter aortaventilimplantasjon). Begge døde utenfor sykehus, og dødsårsaken er ukjent hos begge.

Transvalvulær middelgradient over aortaklaffen ble redusert i begge grupper $(p<$
$0,001)$ sammenliknet med preoperative verdier og var lavest postoperativt i gruppen med transkateter aortaventilimplantasjon $(\mathrm{p}=0,001)$ (fig 4). NYHA-klasse var bedre seks måneder etter transkateter aortaventilimplantasjon enn preoperativt $(p<0,001)$ (fig 5). Ved hjelp av ekkokardiografi ble det påvist paravalvulær lekkasje postoperativt hos 17 pasienter i gruppen med kateterbasert implantasjon. Disse var uendret ved seksmånederskontrollen (fig 6). Oppfølgingsdata for NYHA-klasse og paravalvulær lekkasje i gruppen med åpen operasjon foreligger ikke.

\section{Diskusjon}

Korttidsresultatene fra de 25 første pasientene behandlet med transkateter aortaventilimplantasjon ved Universitetssykehuset Nord-Norge er oppmuntrende. Vi har vist at man med et erfarent multidisiplinært team, god opplæring i metoden og grundige forhåndsvurderinger av pasientene kan oppnå like gode eller bedre resultater enn i en sammenliknbar gruppe operert konvensjonelt. En 30-dagersmortalitet på 4 \% i denne selekterte høyrisikogruppen er lavere enn i tidligere publiserte materialer (15). Kontrollgruppen hadde en 30-dagersmortalitet på $16 \%$, som samsvarer med denne gruppens logistiske EuroSCORE. Det er kjent at mortaliteten overestimeres med EuroSCORE (16), men vi må se den i lys av at dette var en selektert gruppe høyrisikopasienter og at antallet var lavt. I treårsperioden 2006-09 var 30 -dagersmortaliteten $6,5 \%$ for alle over 80 år behandlet ved Universitetssykehuset

Tabell 2 Per- og postoperative data

\begin{tabular}{|c|c|c|c|}
\hline & $\begin{array}{c}\text { Åpen operasjon } \\
2008-09 \\
(\mathrm{n}=25)\end{array}$ & $\begin{array}{c}\text { Transkateter } \\
\text { aortaventilimplantasjon } \\
2008-09 \\
\text { (n }=25)\end{array}$ & P-verdi \\
\hline Implantasjonssuksess & & $100 \%$ & - \\
\hline Konvertert til åpen & & 0 & - \\
\hline Endret tilgang peroperativt & & 1 & - \\
\hline $\begin{array}{l}\text { Gjennomsnitt operasjonstid, min } \\
\text { (spredning) }\end{array}$ & $174(114-244)$ & $122(90-290)$ & $<0,001$ \\
\hline $\begin{array}{l}\text { Gjennomsnitt klaffestørrelse, mm } \\
\text { (spredning) }\end{array}$ & $22,9(19-27)$ & $24,3(23-26)$ & $<0,01$ \\
\hline Reoperasjon pga. blødning & 1 & 3 & 0,60 \\
\hline Reoperasjon pga. infeksjon & 3 & 0 & 0,23 \\
\hline \multicolumn{4}{|l|}{ Sykehusdager universitetssykehuset } \\
\hline - Totalt & 323 & 255 & 0,86 \\
\hline - Median & 11 & 9 & - \\
\hline - Intensivdøgn & 38 & 0 & 0,32 \\
\hline Postoperativt hjerteinfarkt & 1 & 0 & 1,0 \\
\hline Postoperativt cerebralt infarkt & 1 & 0 & 1,0 \\
\hline Mortalitet (30 d/i sykehus) & 4 & 1 & 0,35 \\
\hline \multicolumn{4}{|l|}{ Transfusjoner, antall enheter } \\
\hline$-S A G$ & 88 & 59 & 0,03 \\
\hline - Plasma & 36 & 29 & 0,32 \\
\hline - Trombocytter & 17 & 6 & 0,18 \\
\hline
\end{tabular}

Nord-Norge med åpen operasjon med eller uten aortokoronar bypass.

John G. Webb fra St. Paul's Hospital, Vancouver, har publisert langtidsdata fra 168 pasienter med aortastenose behandlet med transkateter aortaventilimplantasjon. Median observasjonstid var 221 dager (maks $>3$ år) (17). Overlevelsen etter én, 12 og 24 måneder var henholdsvis $89 \%, 74 \%$ og $61 \%$. I dette materialet var det signifikant lavere dødelighet hos de sist behandlede, noe som illustrerer positiv læringskurve og utvikling av teknikk og utstyr. Den vanligste sene klafferelaterte hendelsen var blødning relatert til gastrointestinal sykdom. Dette så man oftest hos pasienter som fikk antikoagulasjonsbehandling og dobbel platehemming. Nå velger man å unngå slik trippelbehandling.

Tre pasienter i gruppen med transkateter aortaventilimplantasjon, som alle sto på klopidogrel eller warfarin, ble reoperert for blødning. To av reoperasjonene var etter transapikal tilgang, og det var blødning fra apeks i ett av tilfellene. Ingen av reoperasjonene var dramatiske. To transapikale prosedyrer var kompliserte, med peroperative blødninger under lukking av selve apekstilgangen. Begge pasientene var kvinner over 87 år som hadde stått på stereoidbehandling over lengre tid. Transfusjonene til disse to pasientene utgjorde nærmere halvparten av det totale transfusjonsvolumet hos pasientene med transkateteraortaventilimplantasjon. Etter disse to episodene har vi nå blodsparende tiltak (cellsaver) i beredskap ved transapikale prosedyrer. Apeksblødninger er beskrevet fra andre sentre og representerer en utfordring hos eldre kvinner som har fått langvarig stereoidbehandling $(18,19)$.

Pasientseleksjonen er et kritisk element for å oppnå gode resultater med behandlingsmetoden (18). De som vurderes, må ha symptomgivende aortastenose og betydelig økt risiko ved konvensjonell kirurgi. I utredningen må man ta hensyn til at det hos dem som skal tilbys prosedyren, må være potensial for symptombedring, at de må ha leveutsikter på over ett år og at de må være motiverte.

Aorta og bekkenkar må kartlegges grundig med tanke på slynget forløp, diameter og aterosklerotiske forandringer, da disse faktorene er viktige når det gjelder valg av tilgang. De som har slyngede, trange og betydelig forkalkede bekkenkar og/eller aorta, bør gjennomgå transapikal implantasjon for å unngå vaskulære komplikasjoner. Transfemoral teknikk velges når det er mulig, ut fra angiografi og CT-undersøkelse av bekkenkar og aorta. CT-undersøkelse med tredimensjonal rekonstruksjon muliggjør grundig anatomisk vurdering og er særlig nyttig for å avklare eventuell ringformet kalk, som hindrer fleksibilitet og ekspansjon av karet. Minste akseptable bekkenkardiametermål er $7 \mathrm{~mm}$ og $8 \mathrm{~mm}$ for henholdsvis $22 \mathrm{~F}$ - og 24 F-katetrene (for Edwards SAPIEN-klaffene). Neste generasjons utstyr, som var tilgjengelig i Norge fra april 2010, er redusert til 18 F og krever mi- 
nimum $6 \mathrm{~mm}$ kardiameter. Det er også viktig å vurdere grad av aterosklerose i aortabuen med tanke på embolifare.

Grundig preoperativ ekkokardiografisk vurdering av anatomiske forhold, sentral hemodynamikk og eventuelle tilleggslidelser (pulmonal hypertensjon, mitralinsuffisiens, redusert kontraktilitet m.m.) er viktig for valg av strategi og for å kunne vurdere risikoen ved inngrepet. Erfaringer fra andre sentre har vist at nedsatt venstre ventrikkelfunksjon utgjør en risikofaktor når det gjelder 30-dagersmortalitet. Av den grunn valgte vi å behandle en av pasientene som hadde betydelig svekket venstre ventrikkel-funksjon med sirkulasjonsstøtte fra hjerte-lungemaskin. Transøsofageal ekkokardiografi er avgjørende for valg av klaffestørrelse, da man ved transtorakal ekkokardiografi vanligvis vil overestimere diameter av a. annulus. Med dagens Edwards SAPIEN-klaffer kan man behandle pasienter med annulusdiameter på $18-25 \mathrm{~mm}$.

Flere algoritmer er utviklet for å risikostratifisere hjertekirurgiske pasientpopulasjoner. Algoritmene er utviklet for å estimere risiko for død i en gruppe pasienter med en gitt risikoprofil og er ikke egnet til å predikere utfallet hos enkeltpasienter. Den mest brukte risikokalkulatoren i Europa er EuroSCORE (16), som overestimerer risikoen ved hjertekirurgi, hevdes det $(16,20)$. Med EuroSCORE er det høy operativ risiko ved en kalkulert 30-dagersmortalitet på > $15 \%$.

Selv om risikokalkulatorene kan være nyttige i pasientseleksjonen, er det flere faktorer som ikke er inkorporert i algoritmenefor eksempel anatomiske brystveggsabnormaliteter, svært forkalket torakalaorta (porselensaorta), tidligere strålebehandling av mediastinum, tidligere mediastinitt eller generell skjørhet hos pasienten. Man må også ta $\mathrm{i}$ betraktning at kalkulatorene er utviklet på bakgrunn av resultater etter utført kirurgi, noe som begrenser nytten hos antatt inoperable pasienter. Av den grunn er klinisk skjønn helt sentralt i pasientenutvelgelsen.

Pasientene intuberes og holdes lett sederte under inngrepet. Etter vår vurdering er de anestesiologiske utfordringene på linje med de problemene man ville forvente ved åpen kirurgi hos samme pasientkategori, og monitoreringsnivået er valgt ut fra dette. Videre har man beredskap for umiddelbar konvertering til åpen kirurgi og hjerte-lungemaskin-støtte dersom dette skulle være påkrevd. Etter inngrepet vekkes og ekstuberes pasientene på hybridlaboratoriet umiddelbart etter prosedyren.

Beregnet kostnad for en transkateter aortaventilimplantasjon ligger på rundt 280 000 kroner. Dette er mer enn det dobbelte av hva konvensjonell aortaklaffekirurgi koster. Kostnaden per leveår vil være høy så lenge prosedyren er forbeholdt pasienter over 80 år. Denne kostnaden vil falle betraktelig hvis behandlingen blir aktuell også i yngre aldersgrupper. Før den tas i bruk for yngre

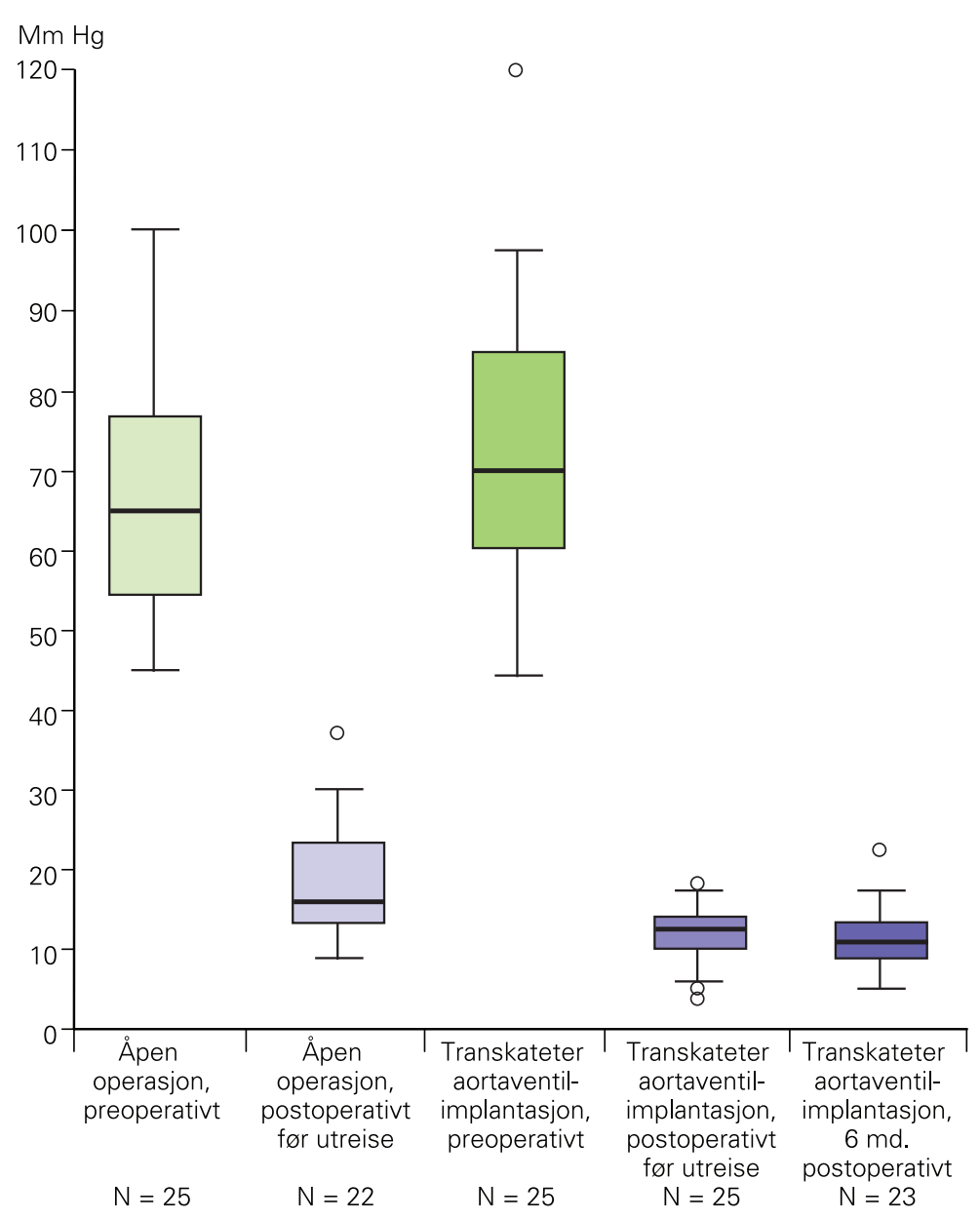

Figur 4 Ekkokardiografiske middelgradienter pre- og postoperativt for transkateter aortaventilimplantasjon og åpen operasjon. Boksplottene viser median, øvre og nedre kvartil, minimumsog maksimumsverdi samt utenforliggere (outliers). Den transvalvulære middelgradienten over aortaklaffen var lavere postoperativt ved utreise sammenliknet med preoperativt ved begge behandlingsmetoder $(p<0,001)$ og lavere postoperativt ved utreise i gruppen med transkateter aortaventilimplantasjon sammenliknet med åpen operasjon ( $p=0,001)$. To pasienter behandlet med transkateter aortaventilimplantasjon var døde før seksmånederskontrollen. Tre pasienter behandlet med åpen operasjon døde under sykehusoppholdet

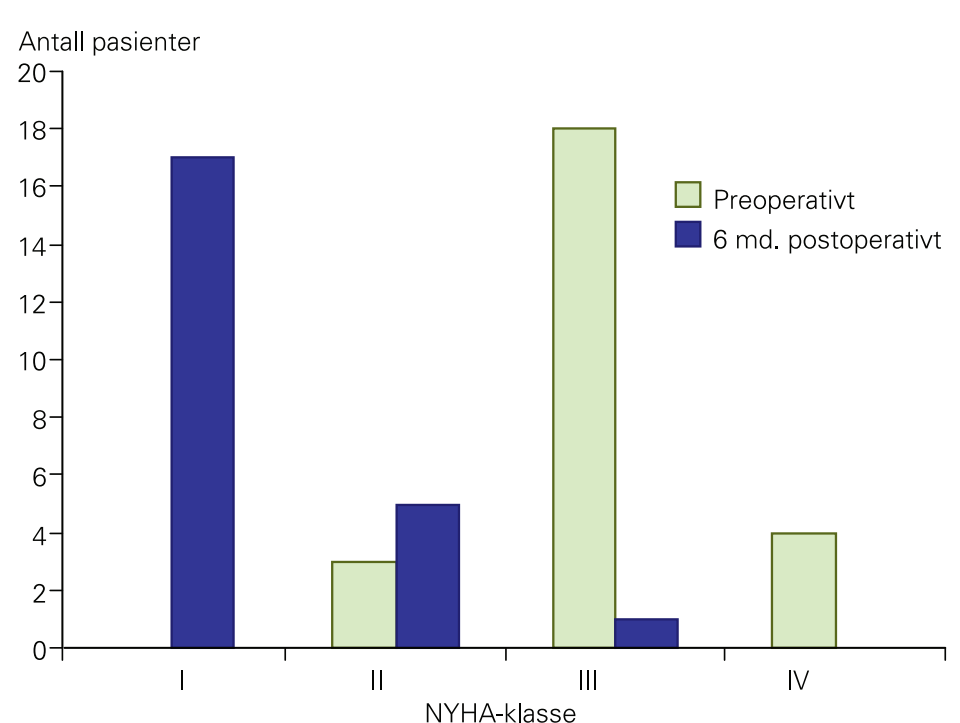

Figur 5 NYHA-klasse pre-og postoperativt ved transkateter aortaventilimplantasjon. NYHA-klasse var bedre $6 \mathrm{md}$. postoperativt enn preoperativt ( $p<0,001)$. To pasienter døde før seksmånederskontrollen 


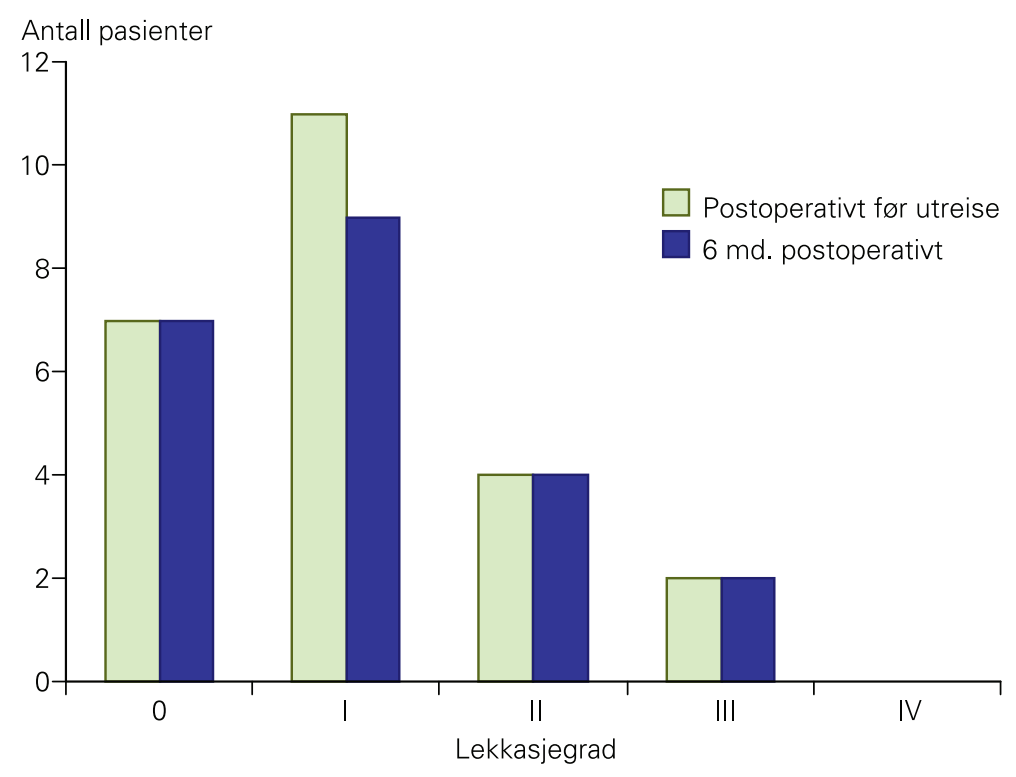

Figur 6 Paravalvulær lekkasje postoperativt ved transkateter aortaventilimplantasjon. To pasienter var døde før seksmånederskontrollen

pasientgrupper må det foreligge langtidsstudier som dokumenterer minst like gode resultater som ved konvensjonell kirurgi.

Et godt samarbeidende multidisiplinært team av hjerteanestesiologer, kardiologer, radiologer og kar-/thoraxkirurger er nødvendig for å oppnå gode resultater. I denne sammenheng er det fundamentalt at det ikke oppstår revirtenkning og kamp om pasientene. Vi har i tillegg valgt å begrense størrelsen på teamet og holde implantasjonsprosedyren på få hender for å bygge tilstrekkelig erfaring hos den enkelte.

\section{Konklusjon}

Basert på korttidsresultater med oppfølgingstid på inntil 16 måneder er transkateter aortaventilimplantasjon en trygg metode for eldre med symptomgivende aortastenose som er vurdert som inoperable ved åpen kirurgi eller der åpen kirurgi vil innebære en uakseptabelt høy risiko. Resultatene er likeverdige eller bedre enn resultatene ved tradisjonell åpen kirurgi hos en gruppe med sammenliknbar risikoprofil, vurdert ut fra Euro-
SCORE. Suksessfaktorene for metoden er grundig opplæring, pasientseleksjon og utredning samt et velfungerende multidisiplinært team.

Oppgitte interessekonflikter: Alle forfatterne har deltatt på Edwards' obligatoriske treningsprogram, med én reise til simulatorsenter i Frankfurt og én reise til London.

e-ramme 1 finnes iartikkelen på www. tidsskriftet.no

\section{Litteratur}

1. Nkomo VT, Gardin JM, Skelton TN et al. Burden of valvular heart diseases: a population-based study. Lancet 2006; 368: 1005-11.

2. Norsk thoraxkirurgisk forening. Hjertekirurgiregisteret. www.legeforeningen.no/id/84429.0 (22.12.2010).

3. Varadarajan P, Kapoor N, Bansal RC et al. Clinical profile and natural history of 453 nonsurgically managed patients with severe aortic stenosis. Ann Thorac Surg 2006: 82: 2111-5.

4. Kvidal P, Bergström R, Hörte LG et al. Observed and relative survival after aortic valve replacement. J Am Coll Cardiol 2000; 35: 747-56

5. Schwarz F, Baumann P. Manthey J et al. The effect of aortic valve replacement on survival. Circulation 1982; 66: 1105-10.
6. lung B, Cachier A, Baron G et al. Decision-making in elderly patients with severe aortic stenosis: why are so many denied surgery? Eur Heart J 2005; 26 : 2714-20.

7. Andersen HR, Knudsen LL, Hasenkam JM. Transluminal implantation of artificial heart valves. Description of a new expandable aortic valve and initial results with implantation by catheter technique in closed chest pigs. Eur Heart J 1992; 13 : $704-8$.

8. Cribier A, Eltchaninoff H, Tron $\mathrm{C}$ et al. Early experience with percutaneous transcatheter implantation of heart valve prosthesis for the treatment of end-stage inoperable patients with calcific aortic stenosis. J Am Coll Cardiol 2004; 43: 698-703.

9. Webb JG, Chandavimol M, Thompson CR et al. Percutaneous aortic valve implantation retrograde from the femoral artery. Circulation 2006; 113: $842-50$.

10. Lichtenstein SV, Cheung A, Ye J et al. Transapical transcatheter aortic valve implantation in humans: initial clinical experience. Circulation 2006; 114: $591-6$

11. Gedde-Dahl S. Hjertepasient døde i omstridt behandling. Aftenposten 2.7.2009. www. aftenposten.no/nyheter/iriks/article3150600.ece (22.12.2010).

12. www.kvalitetogprioritering.no/Saker/12355.cms (22.12.2010).

13. Roques F, Michel P, Goldstone AR et al. The logistic EuroSCORE. Eur Heart J 2003; 24: 881-2.

14. Webb JG, Pasupati S, Achtem L et al. Rapid pacing to facilitate transcatheter prosthetic heart valve implantation. Catheter Cardiovasc Interv 2006; 68: 199-204.

15. Bande M, Michev I, Sharp AS et al. Percutaneos transcatheter aortic valve implantation: past accomplishments, present achievements and applications, future perspectives. Cardiol Rev 2010; 18: 111-24.

16. Grossi EA, Schwartz CF, Yu P-J et al. High-risk aortic valve replacement: are the outcomes as bad as predicted? Ann Thorac Surg 2008; 85: 102-7.

17. Webb JG, Altwegg L, Boone RH et al. Transcatheter aortic valve implantation: impact on clinical and valve-related outcomes. Circulation 2009; 119: $3009-16$

18. Al-Attar N, Himbert D, Descoutures F et al. Transcatheter aortic valve implantation: selection strategy is crucial for outcome. Ann Thorac Surg 2009; 87: 1757-63

19. Wendler O, Walther T, Nataf P et al. Trans-apical aortic valve implantation: univariate and multivariate analyses of early results from the SOURCE registry. Eur J Cardiothorac Surg 2010; 38: $119-27$.

20. Pinna-Pintor $P$, Bobbio $M$, Colangelo $S$ et al. Inaccuracy of four coronary surgery risk-adjusted models to predict mortality in individual patients. Eur J Cardiothorac Surg 2002; 21: 199-204.

Mottatt 25.1. 2010, første revisjon innsendt 13.7. 2010, godkjent 28.10. 2010. Medisinsk redaktør Lars Inge Frich. 